\title{
1. An evolutionary overview of the ownership, governance and strategy of Mediobanca: from the kingmaker of Italian capitalism to a large financial conglomerate Alessandro Zattoni and Francesca Cuomo
}

\section{INTRODUCTION}

The chapter presents the evolution of the ownership structure, the corporate governance and the strategy of Mediobanca. This story may be of great interest to both corporate governance scholars and practitioners, for several reasons.

First, the history of Mediobanca is closely intertwined with the evolution of the Italian banking system. At the beginning of the twentieth century, the national banking system was characterized by the presence of universal or mixed banks. In 1936, after the Wall Street crash, the new banking law separated the commercial banks from the investment banks in order to promote the principle of specialization of the financial institutions. More recently, in 1993, the legislator partially reverted to the previous rules by allowing banks to own shareholdings in, and to finance long-term investments of, industrial companies, even if within certain limits. In the period of time between its birth and the new banking law, Mediobanca was the dominant investment bank in the national financial market. At the turn of the new millennium, the bank transformed itself by divesting $€ 6$ billion of shares of Italian listed companies and by developing the commercial bank business.

Second, the history of Mediobanca is strictly connected with that of Italian capitalism over time. Since the 1970 s and until the end of the last century, Mediobanca played an influential role in the national economy by supporting the development of the Italian family-based capitalism model. In particular, Mediobanca supported the creation of a stable group of shareholders controlling large industrial groups through the use of control-enhancing mechanisms, such as syndicate agreements, dual class shares and pyramidal groups. The influence of the bank in this period 
was so strong that some commentators considered Mediobanca to be the 'kingmaker' of the Italian economic system.

Third, the history of Mediobanca is intertwined with the vision and life of Enrico Cuccia, its leader for about 50 years. Cuccia was a person with a strong personality and leadership style. He designed stable ownership and governance structures for the bank so that it could pursue its own interests with full autonomy from its major shareholders. He led the banking institution with the purpose of impacting positively upon the development and growth of the Italian economic system. While some of his decisions have been strongly criticized by commentators, he was one of the most admired and reputed Italian and European bankers of the twentieth century.

In sum, the chapter provides a contribution to the literature on the Italian banking industry, national capitalism models and leadership styles. Below, we summarize the history of Mediobanca from its birth to today, and we present the implications for corporate governance literature and practice.

\section{THE ITALIAN CAPITALISM MODEL}

The Italian industrialization process started at the end of the nineteenth century, significantly later than in other countries such as the United States (US) and the United Kingdom (UK) (Gerschenkron, 1962). In this phase, the national economy was dominated by both state-owned companies and large universal banks (that is, Banca Commerciale Italiana, Credito Italiano and Banco di Roma).

The state created and directly controlled companies operating in many industries. Two large mixed or universal banks, Banca Commerciale Italiana and Credito Italiano, developed a network of shareholdings in the largest industrial companies. In order to reinforce their control of these companies, the mixed banks nominated representatives on the board of directors and also, sometimes, the top managers. Both the state and the mixed banks financed the growth of the Italian economy and, particularly, of companies operating in capital-intensive industries (for example, public utilities, steel, mining). In addition, they provided financial resources and strategic advice to companies that faced a high risk of financial distress due to the high leverage or the fact that they were less profitable than other companies.

At the beginning of the 1930s, the world economic recession and the effects of the Wall Street crisis radically changed the structure of the national economy. The crisis severely hit the industrial companies and the mixed banks that controlled them. In order to prevent the 
collapse of the national economy, the state established the Istituto per la Ricostruzione Industriale (IRI) which took control of the largest banks and of their controlled companies. After this reorganization, the state became the owner of 40 percent of the shareholdings of several Italian listed companies, including major companies in the steel, heavy machinery, shipbuilding and energy sectors. In 1936, with the issue of the new banking law, the state introduced a clear separation between commercial banks and industrial companies to avoid the risk that temporary financial deficiencies of the main national non-financial companies could lead to the collapse of the entire economic system. The new regulatory framework was based on three pillars: (1) the rigorous separation of commercial and investment banks; (2) the large influence of the state on the banking industry through both direct ownership and indirect regulation; and (3) the impossibility for banks to buy equity stakes in industrial firms, while allowing the opposite (Piluso, 2010).

In the following years, the size of the Stock Exchange remained limited in terms of both stock capitalization and number of listed companies. The state promoted the development of special financial institutions - such as Istituto Mobiliare Italiano (IMI) - that collected financial resources through the issue of long-term bonds and used these resources to finance the long-term investments of large companies. The commercial banks, operating under the control of the Bank of Italy, collected money in the short term through savings and deposit accounts and used these resources to finance short-term investments by families and firms. The socalled 'Beneduce system' - whose name derives from Alberto Beneduce, the manager appointed by Mussolini to reorganize the entire banking industry - was intended to protect families' savings and to support the stable formation and allocation of financial resources (Piluso, 2010).

With the end of the mixed banks and the marginal role of the Stock Exchange, a new model of control started to complement the state intervention in the economy. At the end of the 1930s the control of a large industrial group, Bastogi, shifted into the hands of a shareholders' syndicate including the most important private groups (for example, Fiat, Pirelli, SMI, Edison), IRI and some financial institutions (Segreto, 1997). The Bastogi experience represented the first tentative attempt to control a large company through a syndicate agreement among private shareholders, a model of control that would become widespread after the Second World War. The shareholders involved in these operations were typically wealthy families controlling large private groups established at the turn of the nineteenth century, such as the Agnelli Family (Fiat), the Pirelli family (Pirelli), the Pesenti family (Italcementi), the Orlando family (SMI) and the Falck family (Acciaierie e Ferriere Lombarde Falck). These groups 
were localized in the northern area of the country and, for this reason, they are called the 'galaxy of the north' (Colajanni, 1991).

\section{THE ORIGINS OF MEDIOBANCA}

Mediobanca was founded in 1946 - under the initiative of Raffaele Mattioli, the chief executive officer (CEO) of Banca Commerciale Italiana - by the three largest banks in the country: Banca Commerciale Italiana (now Intesa Sanpaolo) and Credito Italiano (now Unicredit) each with 35 percent of the share capital, and Banco di Roma (merged with Unicredit in 2007) with 30 percent. During its first decade, as a financial arm of the three largest national banks, Mediobanca provided mediumlong term financial resources to large industrial groups and played an influential role in the creation of underwriting syndicate agreements for equity and debt issued by large private groups. Thanks to the support of the three founding banks in the placement of securities and bonds, Mediobanca soon became the major player in the market. While IMI, the largest state-owned financial institution operating in the long term, preferred to finance investment projects promoted by the state, Mediobanca devoted its resources to the development of large private groups (La Malfa, 2014).

Its leader for about 50 years was Enrico Cuccia, whose personality was characterized by professionalism and mystery at the same time. He was the son-in-law of Alberto Beneduce, who argued that the management of state-owned institutions (such as IMI or IRI) should pursue economic efficiency in the same way as private companies. Cuccia learned Beneduce's philosophy in his early work experience, first in the London branch of the Bank of Italy (1931), then in the IRI group (1934) and finally, after experience in Ethiopia, in the Banca Commerciale Italiana (1938). During this experience at the Banca Commerciale led by Raffaele Mattioli, Cuccia started to develop the idea to create a new financial institution.

Cuccia became the general manager of Mediobanca and a few years later, in 1949, the CEO. His term of office ended officially in 1982, but in reality he led the bank until his death in 2000. As the best interpreter of the Beneduce's philosophy, he managed a state-owned bank following a privately owned approach, that is, behaving as a faithful and professional grand commis d'etat. Cuccia had a pessimistic view of the ability of market forces to promote the long-term development of the national economy, and his primary objective was to avoid both the nationalization and the shrinking of major private groups. To meet this objective, he created close relationships with some foreign merchant banks (such as Lazard, Paribas and Lehman Brothers) that introduced Mediobanca to the international 
financial arena. At the same time, he preserved the bank's autonomy from the interference of Italian politicians and major shareholders of the bank (Zamagni, 2009).

In the first period, Mediobanca focused both on providing advisory services to large companies issuing bonds and on placing these bonds with the public, thanks to the retail branches of the three IRI banks. The bank rapidly became the dominant player in this lucrative market and managed the placement of 85 percent of all bonds issued by private companies between July 1948 and June 1949 (Piluso, 2005). From 1951, Mediobanca also started to manage the placement of shares. The bank played a key role in helping large private and state-owned groups to complement selffinancing and bank loans with the issue of bonds and equity. This role was highly critical if we consider that the information released by firms to the public in that period was limited also due to the multiple loans practice. ${ }^{1}$ In this context, Mediobanca guaranteed the quality of the financial instruments issued by private companies through a detailed and rigorous analysis of their economic and financial information. In the national economic system, Mediobanca quickly gained a strong reputation as an autonomous and trustworthy financial institution. Consequently, its assets and operations grew exponentially.

In the early 1950s, Mediobanca started to create a business group offering a wide range of financial services. The companies acquired included: (1) Spafid, specialized in fiduciary management of assets; (2) Compass, operating in the consumer credit industry; and (3) a couple of trading companies aimed at supporting the exports of Italian companies in Africa. At the same time, Mediobanca started to buy minority shareholdings in large companies (for example, Bastogi, Assicurazioni Generali, Caffaro, Pirelli, Mondadori, Fiat) with the specific objective to stabilize their control in the hands of a coalition of shareholders.

With the increase of the bank's share capital in 1955, Mediobanca improved its financial solidity and opened up its shareholdings to private foreign shareholders such as Lazard and Lehman. At the same time, the three IRI banks signed a syndicate agreement to keep the control of the bank. Then, ten years after the bank was founded, Cuccia promoted the listing of Mediobanca. However, after the initial public offering (IPO) took place in 1956, the control of the bank still remained firmly in the hands of the three IRI banks. Two years later, in 1958, the corporate governance of Mediobanca changed significantly as a secret syndicate agreement was signed among the founding banks - which still held 56 percent of the shares - and a few private shareholders (that is, Lazard, Lehman Brothers, Lazard Brothers, Sofina, Berliner Handelgeselleschaft and, later, Pirelli). According to the agreement, 


\section{Handbook on corporate governance in financial institutions}

the control of Mediobanca was in the hands of an executive committee with an equal representation of state-owned and private shareholders. Thanks to the syndicate agreement and a co-operative agreement with the foreign banks, the management of Mediobanca increased its autonomy from the three IRI banks and expanded the international financial services offered.

In the following years, Mediobanca gradually became the house bank of the Italian family groups (Segreto, 1997). To achieve this, the bank invested extensively in its consulting and research team which became a key resource for widening the services it offered to industrial companies. Both competences in analyzing annual reports and industrial plans, and the specialization of industry analysts, were crucial for evaluating the risks implied in medium-term financial loans to large industrial firms (for example, to sustain their export strategy). They were also crucial in actively providing consulting services to companies facing strategic or financial problems due to wrong investments or unexpected market difficulties. In addition, Mediobanca opened foreign branches and bought shareholdings in foreign banks located in emerging economies with high growth prospects. Thanks to its international network, the bank was able to finance the foreign expansion of large Italian groups such as Impregilo and Fiat (Piluso, 2005).

In 1964, Mediobanca coordinated a group of companies and banks (including Fiat, Pirelli and IMI) aimed at providing financial resources and strategic leadership to prevent Olivetti's financial collapse. Two years later, in 1966, a group of private entrepreneurs promoted the merger of two of the largest Italian companies, Montecatini and Edison, with the purpose of creating a more solid chemical group: Montedison. The operation, developed thanks to the financial support and advice of Mediobanca, did not solve the underlying problems of the two firms. In order to find a solution to the tension between the state - which through ENI (Ente Nazionale Idrocarburi) bought a large shareholding of Montedison - and the private groups, a syndicate agreement was created whereby stateowned and private companies each controlled 49 percent of share capital, and Mediobanca played a decisive role thanks to the remaining 2 percent. These operations marked the transformation of Mediobanca from a pure financial advisor to a key player in the country. Since then, the merchant bank was more and more actively involved in the reorganization of large private groups, supporting their long-term stability through mergers and acquisitions (M\&A), divestments and lay-offs. Mediobanca was much more than a typical investment bank supporting large private groups, it was a bank aimed at pursuing political economy objectives through the reorganization of entire industries. 


\section{THE RISING IMPORTANCE OF MEDIOBANCA IN THE ITALIAN ECONOMIC SYSTEM}

After a long and sustained period of growth, the economic crisis of the 1970s resulted in the recession of the national economy, with high inflation and interest rates. The crisis severely hit the largest industrial groups, reducing their profitability and increasing their leverage, due to a large growth of the short-term financial debt with banks. In these turbulent years, industrial companies lost their prominence in the national economy and started to rely on banks to finance future investments (McCann, 2000).

The previous experiences with Bastogi, Olivetti and Montedion led, in this period, to the consolidation of a new model of control in Italian capitalism, a model where the control was exercised by several shareholders coordinated thanks to a syndicate agreement and the financial and strategic support of Mediobanca. Enrico Cuccia believed that the stability of control in the hands of a wealthy entrepreneurial family facilitated the development of long-term strategies. In his view, a stable ownership structure could both benefit the long-term survival of the firm and contribute positively to the growth of the national economy (McCann, 2000).

To pre-empt the financial collapse of several large companies, Mediobanca promoted banking trusts aimed at providing both financial resources and strategic advice to overcome the crisis. Considering that the banking law forbade commercial banks from buying shares of industrial companies, and that the Stock Exchange played a limited role in the reallocation of control, the Mediobanca proposal immediately became popular. Mediobanca's success was due to the fact that it was the only national financial institution that had three strategic assets: availability of financial resources, sophisticated technical and financial competencies, and strong relationships with primary international financial institutions.

Cuccia and Mediobanca become the key actors of the national economic system. Their role in this difficult period was crucial to avoiding the nationalization of private companies facing increasing financial and market difficulties. This was particularly evident in the stabilization of the control of large companies such as Fiat and Montedison, and in the reorganization of the entire chemical industry through consolidations and mergers. Furthermore, in order to strengthen the competitive position of the few large national private companies, Mediobanca promoted the development of international alliances with foreign groups operating in the same industry. A first operation, aimed at creating a European champion in the car industry by supporting the integration of Fiat and Citroen, broke down after a few years. A second operation, the strategic alliance 
between Pirelli and Dunlop, was more successful and lasted more than ten years, from 1970 to 1981 (Piluso, 2005).

\section{THE PRIVATIZATION OF MEDIOBANCA}

In the 1980s, the national economy restarted its growth. The stock market experienced a long period of development and prosperity, thanks to the growth of the national economy and the new law on investment trusts that facilitated an incoming flow of financial resources from both Italy and abroad. In this positive economic climate, Mediobanca promoted and coordinated several shares and bonds issues by large companies, so increasing its influence on large Italian groups.

Among the major operations, in 1981 Mediobanca brought the control of Montedison back into private hands, together with Fiat, Pirelli, SMI and Bi-Invest. Mediobanca also encouraged the rationalization of production sites, the sale of non-core assets and the reorganization of the entire group to strengthen its competitive position in the market. Later, when Schimberni - the CEO of Montedison nominated by Mediobanca decided to create a public company dominated by managers, Mediobanca supported the takeover of the private agro-industrial group Ferruzzi in order to regain control of the large chemical company. A second major operation was support to the Fiat group in both the acquisition of some companies (for example, Toro, Rinascente, Snia BPD) and the liquidation of the shareholding stake owned by the Libyan Lafico. In this decade, not all operations were successful. For example, the tentative attempt to create a national group in the telecommunication industry by merging Telettra (owned by Fiat group) and Italtel (owned by the state through Stet) failed in 1987 due to divergences among the shareholders (Piluso, 2005).

At the end of the 1980s, the decision-making autonomy of Mediobanca was increased and stabilized thanks to the privatization process. In 1988, after a long and debated negotiation, the three IRI banks decreased their shareholdings in Mediobanca from 56.9 percent to 25 percent of the entire share capital. At the same time, the private shareholders, including industrial groups (such as Pirelli, Agnelli, De Benedetti, Ferrero, Ferruzzi, Marzotto) and financial institutions (such as Lazard, Berliner HandelsGesellschaft, Assicurazioni Generali, La Fondiaria), bought enough shares to equal the shareholdings held by the three IRI banks. Then control was stabilized through an agreement between these two groups of shareholders having equal rights for the appointment of board members (La Malfa, 2014).

With the privatization of Mediobanca and the signing of this new 
syndicate agreement, the leadership structure of the bank changed: Cuccia became the honorary chairman, his protégé Vincenzo Maranghi the CEO, and Francesco Cingano (former CEO and later chairman of Banca Commerciale) the chairman of the bank. The leadership, the professional competence and the powerful relationships of the 'troika' (Cuccia, Maranghi and Cingano) continued to be particularly important to preserve the autonomy of the bank from its key shareholders. In addition to the shareholding changes, Mediobanca's independence from the IRI banks was also strengthened by a shift in the technical tools used to collect financial resources. In the second half of the 1980s, profiting from the growing role of the financial markets in the national economy, the bank increasingly substituted the financial certificates distributed through the retail banks with the direct issue and sale of bonds to families and companies (Piluso, 2005).

The privatization of Mediobanca raised some negative comments as it made more evident the potential conflict of interests between the bank and its shareholders. The entry of new private shareholders and the disclosure of the syndicate agreement made it clear that, on the one hand, Mediobanca supplied financial funds, provided strategic and financial advice and bought small shareholdings of large private industrial and financial groups. On the other hand, the same private clients bought shareholdings in Mediobanca and nominated their representatives to its board of directors. As such, the formalization of the agreement highlighted the existence of a wealthy club of entrepreneurs - the so-called 'noble wing' (ala nobile) or 'fine drawing room' (salotto buono) of Italian capitalism with favourable access to the financial resources, the strategic and financial advice, and the international links of Mediobanca. Belonging to this core group of industrial and financial companies was certified by the ownership of a shareholding in Mediobanca and in Gemina (later renamed Holding di Partecipazioni Industriali), that for a period of time became the new holding company - after the Bastogi group in the late 1930s - of the private industrial groups.

\section{MEDIOBANCA AS THE KINGMAKER OF ITALIAN CAPITALISM}

In the last decades of the nineteenth century, Mediobanca played a central role in the Italian capitalism model thanks to its financial relationships with both the large banks and the large private groups. In an economic system where borrowing financial resources from banks was more important than raising capital by going public, banks played a prominent role. 
In such a context, Mediobanca was the trusted actor that matched the offer of and the demand for financial resources.

Beyond providing financial resources, Mediobanca played the role of 'white squire', that is, of a financial company that, without being involved in the day-to-day management of the group, helped wealthy entrepreneurial families to keep control of large industrial groups. During the 1980 s, profiting from the favorable market conditions, Mediobanca helped majority shareholders to create a web of mutual shareholdings that reinforced and stabilized their position of control at the head of the groups. These minority shareholdings, if aggregated, were equal to, and sometimes also greater than, the shareholdings owned by the wealthy entrepreneurial family controlling the group. The value of the inter-group shareholdings equaled 6.4 percent of the gross capitalization of the Milan Stock Exchange at the end of 1987, and about one-third of the inter-group shareholdings were held by Mediobanca (Brioschi et al., 1990).

These shareholdings were characterized by continuous adjustments whose major purpose was to create a stable group of controlling shareholders at the top of the group. First, 95 percent of the inter-group shareholdings were concentrated in common shares, the only class with full voting rights according to the Italian commercial law applicable at that time. Second, during the 1980s shareholdings in subsidiaries where the entrepreneurial family had a stable control were sold, and substituted with shareholdings in holding companies in which the controlling family owned less than the majority of the voting rights. Finally, the strategic and financial alliance between the wealthy entrepreneurial families and Mediobanca was usually formalized through syndicate voting or through blocking pacts or agreements, that is, agreements among shareholders that, respectively, bound them to vote in the same way at the assembly meetings, or prevented them from selling their shares to investors outside the syndicate (Zattoni, 1999).

This web of mutual shareholdings, reinforced by syndicate agreements, also determined the diffusion of interlocking directorships among Italian listed companies. A previous study (Drago et al., 2011) shows the centrality of the so-called 'Mediobanca galaxy' (the network of companies and shareholders centered around the bank), as it represents about two-thirds of the overall interlocks among large Italian listed companies. Mediobanca was the center of the galaxy, as it connected its shareholders (for example, Credito Italiano, Banca Commerciale Italiana, Ente Cassa di Risparmio di Roma) with its affiliated companies (for example, Generali, Compart and Pirelli).

The mutual shareholdings, the syndicate agreements and the interlocks showed the existence of a club of wealthy entrepreneurial families that 
governed the national economic system. They produced a high interdependence that favored the emergence of a common interest and of collusive behavior (Brioschi et al., 1990; Zattoni, 2006). Several commentators and scholars underline the potential negative consequences of the Mediobanca network for the financial market and the minority shareholders, due to: (1) the dominance of controlling shareholders, who were able to extract private benefits of control; (2) the absence of an active market for corporate control, due to the impossibility of buying the majority of the shares on the Stock Exchange; and (3) the lack of transparency and the persisting asymmetry of information between insiders and outsiders (McCann, 2000; Zattoni, 2000).

\section{MEDIOBANCA AT THE TURN OF THE TWENTIETH CENTURY}

In the 1990s, the Italian government started a massive privatization process aimed at reaching several objectives (such as the reduction of the national debt and the reorganization of the structure of several industries) to boost the Italian Stock Exchange. The privatization process posed serious threats to Mediobanca as it weakened its financial power and threatened the stability of its galaxy. The privatization also included two large stateowned banks, Banca Commerciale Italiana and Credito Italiano, which were important shareholders and supporters of Mediobanca's financial power. In addition, the privatization of several companies and the rising importance of the Stock Exchange opened the possibility for companies to find new industrial allies and to access financial resources outside of the Mediobanca system (McCann, 2000).

Despite the fact that the privatization process could potentially have menaced the power of Mediobanca and opened up the possibility for defection among its allies, this did not happen immediately. The political power of the government of the so-called 'Second Republic' was weak and unstable. Despite the efforts of IRI and of the Italian government to create public companies through a large-scale offer to small and institutional investors, the ownership structure of the large privatized banks looked different within a few weeks of their sale on the market. Enrico Cuccia's vision to create a stable group of investors guaranteeing the stability of management seemed to have been realized as the shareholding of both banks became concentrated in the hands of a few financial institutions and industrial groups (McCann, 2000). Under these conditions, Mediobanca's influence was still high, and some commentators complained about the weakness of the financial market and the lack of public companies on the 
Italian Stock Exchange. The most important decisions about the future ownership, governance and strategy of the largest privatized industrial groups were still taken in the secret rooms of via Filodrammatici - the address of Mediobanca - by Enrico Cuccia.

A second important event at the beginning of the 1990s, specifically in 1993, was the issue of the new banking law based on the principle of despecialization. According to the new legal framework, banking institutions had the same opportunities to operate both in the short term and in the long term (Zattoni and Cuomo, 2015). This implied the possibility of reuniting commercial and investment activities within the same bank or the same banking group. The rebirth of the universal banks produced three related outcomes: (1) the decrease of multi-loan relationships and the growth of more intense firm-bank relationships; (2) the possibility for banks to buy shares of industrial groups to support their long term survival; and (3) the growing development of the bond and equity market for industrial groups (Piluso, 2010).

Mediobanca seemed to be able to take a profit from the evolution of the banking law. For example, when the Ferruzzi group collapsed under the heavy debt accumulated to finance the takeover of Montedison, Mediobanca pre-empted (once again) the failure of the chemical group. Thanks to the possibility for commercial banks to hold minority shareholdings in industrial groups, Mediobanca became the major shareholder of the company and encouraged other commercial banks (for example, Banca Commerciale Italiana, Credito Italiano, Banco di Roma, Istituto Sanpaolo) to swap their loans for equity (Zattoni, 2009).

In April 1994, a new syndicate agreement (that is, a blocking syndicate agreement) of Mediobanca was signed by the three major Italian banks (that is, group A shareholders) holding 25 percent of equity, and a group of national and international private shareholders (that is, group B shareholders) holding 25 percent of equity. Considering that the validity of the agreement was until 2001, the top management team - still under the substantial leadership of Enrico Cuccia - seemed once again able to prolong its autonomy from shareholders.

However, after a few years it became clear that the ability of Mediobanca to design and manage strategic alliances and mergers involving large industrial and financial groups was diminished by recent events. In the second half of the 1990s, both the proposal to merge Compart (the company controlling Montedison) and Gemina to create Super Gemina, and the proposal to merge the Marzotto group with Holding di Partecipazioni (HDP) controlling GFT, Fila and RCS, were both blocked by the shareholders (Piluso, 2005).

In addition, the turmoil in the Italian banking industry at the end of the 
1990s radically transformed the industry through a number of mergers that led to the creation of a few large and powerful banks, such as Intesa, Unicredito and San Paolo-Imi. These banks became more independent from Mediobanca and developed the ambition to become key players in the rich merchant bank industry. For the first time in its history, the leadership of Mediobanca in the national financial system was challenged by large financial institutions. Important and loyal members of the northern galaxy - such as the Fiat group - started to collaborate and develop close links with the emerging financial groups.

\section{MEDIOBANCA IN THE NEW MILLENNIUM}

At the end of the 1990s, several events pushed the media to predict that Mediobanca would have greatly diminished influence on the national economy. Commentators foresaw that the monopolistic position held for decades within the national financial and industrial system would not be sustainable in the future; the relationship system created by Mediobanca would disappear due to the increasing integration of financial markets and the entrance of foreign merchant banks.

First, the long-term stability of the bank's leadership was shaken by two events. Enrico Cuccia died in 2000 and, after 54 years of his continuous service, Mediobanca was forced to build its future plans without the support of his valuable skills and relationships. A few years later, in 2003, Vincenzo Maranghi left his position of CEO of the bank and Alberto Nagel (now the current CEO, in office since July 2007) was appointed as general manager. Commentators say that the change at the apex of Mediobanca was mostly due to Maranghi's supposed inability both to understand the evolution of the national economy and, accordingly, to design a new role for the bank (Piluso, 2005).

Second, the ownership structure of the bank changed significantly in the first two decades of the twenty-first century. First, Banca Commerciale Italiana, which had been the major shareholder and one of the founders of Mediobanca, sold its shareholding to other members of the syndicate in 2000. A second great ally of Cuccia, the Lazard group, sold its shareholdings in both Assicurazioni Generali and Mediobanca in 2001. In addition, a financial vehicle Tredicimarzo was dismantled in 2002 and the Mediobanca shares owned by this company were allocated to its shareholders pro quota. As a result, the individual shareholders were now freer to sell the shares held in Mediobanca and the control of the bank was more contestable. Moreover, a new group of foreign shareholders (group C), composed of Vincent Bollorè and a few other shareholders 
(such as Groupama), bought about 10 percent of the equity and joined the new bank syndicate (Mediobanca, several years(a); R\&S, several years).

Then, following several changes in the ownership structure of Mediobanca, the percentage of shares allocated to the syndicate agreement fell slightly from 56.7 to 54.69 percent in 2005 . Table 1.1 shows the members of the syndicate agreement of Mediobanca in 2005, the total amount of shares owned by the various members (including indirect shares held through a financial vehicle named Consortium) and the shareholders' rights of each group on the appointment of the board. The table shows that beyond group A and group B shareholders - holding 22.47 and 22.35 percent of share capital, respectively - there was a new group, group C, holding 9.87 percent. Members of the syndicate had strong voting power for the board election: group A appointed two deputy chairmen (one appointed by Capitalia, the new name of Banco di Roma after its merger with Bipop Carire in 2002; and one by Unicredito Italiano), up to six directors (at least two of them to be independent) and one out of three effective members of the board of statutory auditors; ${ }^{2}$ group B appointed up to seven board members (at least one to be independent); group $\mathrm{C}$ appointed up to four board members (at least one to be independent). Despite their power, the traditional autonomy of top managers of the bank was guaranteed by the Article 14 of the Articles of Association stating that the CEO should be selected by the managers of the bank.

Third, the corporate governance of Mediobanca evolved over time due to the changes in its ownership structure, with the exit of some historical partners and the entry of new shareholders. The changes in the ownership structure determined changes to the Articles of Association and revisions to the content of the syndicate agreement. In 2006, the financial vehicle Consortium was dismantled and the shares of Mediobanca were allocated proportionally to its members. In 2007, Unicredit sold the shareholding equal to 9.37 percent of share capital - owned by Capitalia before its incorporation. After this sale, Unicredit still retained an important role thanks to a shareholding equal to 8.7 percent, and the new syndicate continued to hold control of the bank with 45.6 percent of the equity. Between 2010 and 2014, several shareholders sold their shares and exited the shareholders' agreement: Groupama group, Unipol and Assicurazioni Generali sold 4.9 percent, 3.3 percent and 2 percent of the share capital, respectively. As a main consequence, the overall percentage of shares syndicated in the new shareholders' agreement (that is, the so-called 'light pact') fell from 45.6 percent to 30.05 percent between 2007 and 2014. Table 1.2 shows that in June 2014, while the CEO was still selected by the top managers of the bank, the rights to appoint members of the board of directors, committees and the board of statutory auditors were slightly changed. 
Table 1.1 The syndicate agreement of Mediobanca, 2005

\begin{tabular}{|c|c|c|c|c|c|}
\hline Main shareholders & $\begin{array}{l}\% \text { of } \\
\text { share }\end{array}$ & Members & Group & Total & $\begin{array}{l}\text { Main shareholders' } \\
\text { rights about board } \\
\text { composition }\end{array}$ \\
\hline $\begin{array}{l}\text { Capitalia } \\
\text { Unicredito Italiano } \\
\text { Mediolanum group } \\
\text { Commerzbank }\end{array}$ & $\begin{array}{l}9.74 \\
9.00 \\
1.96 \\
1.77\end{array}$ & $\begin{array}{l}\text { Yes } \\
\text { Yes } \\
\text { Yes } \\
\text { Yes }\end{array}$ & A & 22.47 & $\begin{array}{l}\text { - Capitalia: } 1 \text { deputy } \\
\text { chairman } \\
\text { - Unicredito Italiano: } \\
1 \text { deputy chairman } \\
\text { - Up to } 6 \text { directors } \\
\text { ( } 2 \text { out of } 6 \\
\text { should be } \\
\text { independent) } \\
\text { - } 1 \text { out of } 3 \text { members of } \\
\text { the statutory board }\end{array}$ \\
\hline Fondiaria-Sai & 3.40 & Yes & \multirow[t]{11}{*}{$\mathrm{B}$} & \multirow[t]{11}{*}{22.35} & \multirow{11}{*}{$\begin{array}{l}\text { Up to } 7 \text { board } \\
\text { members ( } 1 \text { out } \\
\text { of } 7 \text { should be } \\
\text { independent) }\end{array}$} \\
\hline $\begin{array}{l}\text { Milano } \\
\text { Assicurazioni }\end{array}$ & 0.25 & Yes & & & \\
\hline Finsai International & 0.34 & Yes & & & \\
\hline Italmobiliare group & 2.73 & Yes & & & \\
\hline $\begin{array}{l}\text { Assicurazioni } \\
\text { Generali }\end{array}$ & 1.97 & Yes & & & \\
\hline Pirelli \& C. & 1.90 & Yes & & & \\
\hline Fiat & 1.90 & Yes & & & \\
\hline Telecom Italia & 1.90 & Yes & & & \\
\hline Fin Priv SRL & 1.73 & Yes & & & \\
\hline Luigi Zunino & 2.00 & Yes & & & \\
\hline Others & 4.23 & Yes & & & \\
\hline Vincent Bollorè & 4.94 & Yes & \multirow[t]{7}{*}{$\mathrm{C}$} & \multirow[t]{8}{*}{9.87} & \multirow{7}{*}{$\begin{array}{l}\text { - Up to } 4 \text { board } \\
\text { members ( } 1 \text { out } \\
\text { of } 4 \text { should be } \\
\text { independent) }\end{array}$} \\
\hline Groupama & 2.96 & Yes & & & \\
\hline $\begin{array}{l}\text { Santusa Holding } \\
\text { Soc Limitada }\end{array}$ & 1.39 & Yes & & & \\
\hline $\begin{array}{l}\text { Groupe Industriel } \\
\text { Dassault SA }\end{array}$ & 0.58 & Yes & & & \\
\hline Groupama & 1.94 & No & & & \\
\hline Danilo Coppola & 4.57 & No & & & \\
\hline \multirow[t]{2}{*}{$\begin{array}{l}\text { Consortium (other } \\
\text { shares) }\end{array}$} & 5.96 & No & & & \\
\hline & & & $\mathrm{B}+\mathrm{C}$ & & $\begin{array}{l}\text { - } 1 \text { out of } 3 \text { members of } \\
\text { the statutory board }\end{array}$ \\
\hline Total & & & & 54.69 & \\
\hline
\end{tabular}

Source: Consob. 
22 Handbook on corporate governance in financial institutions

Table 1.2 The syndicate agreement of Mediobanca, June 2014

\begin{tabular}{|c|c|c|c|c|c|}
\hline $\begin{array}{l}\text { Main } \\
\text { shareholders }\end{array}$ & $\begin{array}{l}\% \text { of } \\
\text { share }\end{array}$ & Members & Group & Total & $\begin{array}{l}\text { Main shareholders' rights about } \\
\text { board composition }\end{array}$ \\
\hline $\begin{array}{l}\text { Unicredit } \\
\text { group }\end{array}$ & 8.66 & Yes & A & 12.04 & $\begin{array}{l}\text { - Up to } 5 \text { directors ( } 2 \text { out of } 5 \\
\text { should be independent) }\end{array}$ \\
\hline $\begin{array}{l}\text { Mediolanum } \\
\text { group }\end{array}$ & 3.38 & Yes & & & $\begin{array}{l}\text { - } 1 \text { out of } 4 \text { members of the } \\
\text { Remuneration committee } \\
\text { - } 1 \text { out of } 3 \text { members of the } \\
\text { Statutory board. It might } \\
\text { be the chairman of this } \\
\text { committee, if minority } \\
\text { shareholders will not present a } \\
\text { list }\end{array}$ \\
\hline $\begin{array}{l}\text { Benetton } \\
\text { group }\end{array}$ & 2.16 & Yes & B & 12.01 & $\begin{array}{l}\text { - Up to } 7 \text { directors ( } 2 \text { out of } 7 \\
\text { should be independent) }\end{array}$ \\
\hline Pirelli \& C. & 1.83 & Yes & & & - 1 out of 4 members of the \\
\hline Fin Priv SRL & 1.67 & Yes & & & Remuneration committee \\
\hline $\begin{array}{l}\text { Italmobiliare } \\
\text { group }\end{array}$ & 1.57 & Yes & & & $\begin{array}{l}\text { - } 1 \text { out of } 3 \text { members of the } \\
\text { Statutory board }\end{array}$ \\
\hline $\begin{array}{l}\text { Fininvest } \\
\text { group }\end{array}$ & 1.00 & Yes & & & \\
\hline Others & 3.78 & Yes & & & \\
\hline Bollorè group & 6.00 & Yes & $\mathrm{C}$ & 6.00 & $\begin{array}{l}\text { - Up to } 4 \text { directors ( } 2 \text { out of } 4 \\
\text { should be independent) } \\
\text { - } 1 \text { out of } 4 \text { members of the } \\
\text { Remuneration committee } \\
\text { - } 1 \text { out of } 3 \text { members of the } \\
\text { Statutory board, if minority } \\
\text { shareholders will not present a } \\
\text { list }\end{array}$ \\
\hline $\begin{array}{l}\text { Groupama } \\
\text { group }\end{array}$ & 4.93 & No & & & \\
\hline $\begin{array}{l}\text { Fondazione } \\
\text { Cassa di } \\
\text { Risparmio } \\
\text { in Bologna }\end{array}$ & 2.94 & No & & & \\
\hline \multirow{2}{*}{$\begin{array}{l}\text { Fininvest } \\
\text { group (other } \\
\text { shares) }\end{array}$} & 1.06 & No & & & \\
\hline & & & $A+B+C$ & & $\begin{array}{l}\text { - } 1 \text { out of } 4 \text { members of the } \\
\text { Remuneration committee }\end{array}$ \\
\hline Total & & & 30.05 & 30.05 & \\
\hline
\end{tabular}

Source: Consob. 
Table 1.3 The evolution of Mediobanca leadership, 2003-2015

\begin{tabular}{|c|c|c|c|c|c|}
\hline & $\begin{array}{l}\text { 2003-June } \\
2007\end{array}$ & July 2007 & June 2009 & $\begin{array}{l}\text { June } \\
2010-\text { June } \\
2014\end{array}$ & June 2015 \\
\hline $\begin{array}{l}\text { Gabriele } \\
\text { Galateri di } \\
\text { Genola }\end{array}$ & Chairman & & & & \\
\hline $\begin{array}{l}\text { Cesare } \\
\text { Geronzi }\end{array}$ & $\begin{array}{l}\text { Deputy } \\
\text { chairman }\end{array}$ & $\begin{array}{l}\text { Supervisory } \\
\text { Board } \\
\text { Chairman }\end{array}$ & Chairman & & \\
\hline Alberto Nagel & & CEO & $\mathrm{CEO}$ & CEO & CEO \\
\hline $\begin{array}{l}\text { Renato } \\
\quad \text { Pagliaro }\end{array}$ & & $\begin{array}{l}\text { Chairman } \\
\text { Management } \\
\text { Board }\end{array}$ & & Chairman & Chairman \\
\hline Dieter Rampl & & $\begin{array}{l}\text { Deputy } \\
\text { chairman }\end{array}$ & $\begin{array}{l}\text { Deputy } \\
\text { chairman }\end{array}$ & $\begin{array}{l}\text { Deputy } \\
\text { chairman }\end{array}$ & \\
\hline $\begin{array}{l}\text { Carlo } \\
\text { Salvatori }\end{array}$ & $\begin{array}{l}\text { Deputy } \\
\text { chairman }\end{array}$ & & & & \\
\hline $\begin{array}{l}\text { Marco } \\
\text { Tronchetti } \\
\text { Provera }\end{array}$ & & & $\begin{array}{l}\text { Deputy } \\
\text { Chairman }\end{array}$ & $\begin{array}{l}\text { Deputy } \\
\text { chairman }\end{array}$ & $\begin{array}{l}\text { Deputy } \\
\text { chairman }\end{array}$ \\
\hline $\begin{array}{l}\text { Maurizia } \\
\text { Comneno }\end{array}$ & & & & & $\begin{array}{l}\text { Deputy } \\
\text { chairman }\end{array}$ \\
\hline
\end{tabular}

Source: Mediobanca (several years(b)).

In accordance with the revised Articles of Association of Mediobanca, a new agreement was signed in October 2014 by holders of 31.52 percent of the share capital. Among the main parties, only two shareholders held more than 4 percent of the share capital: Unicredit and Bollore group, with stakes equal to 8.65 percent and 7.48 , respectively. ${ }^{3}$ Finally, further changes to the shareholders' agreement were disclosed on 17 December 2014. The wording of the agreement remained unchanged and valid until 31 December 2015, but the overall percentage of shares syndicated to the agreement declined to 31.44 percent.

These changes affected the bank's leadership between 2003 and 2015 (see Table 1.3). A major event occurred in 2007, when the shareholders changed the governance model of Mediobanca from the traditional Italian model to the dualistic one. ${ }^{4}$ This shift was justified by the desire to separate the shareholders' representatives (sitting on the supervisory board) from the top managers of the bank (sitting on the management board). This choice, coherent with Mediobanca's tradition to keep the 
shareholders far from the management of the firm, was aimed at guaranteeing the necessary decision-making autonomy to the top management team. With the new governance model, the chairman of the supervisory board was Cesare Geronzi, previously the powerful chairman of Capitalia which merged with Unicredit in 2007; and the vice-chairman was Dieter Rampl, previously the CEO of Bayerische Hypo- und Vereinsbank Aktiengesellschaft, bought by Unicredit in 2005. On the other hand, the chairman of the management committee was Renato Pagliaro and the CEO was Alberto Nagel, both with long tenure as executives of the bank. In October 2008, the shareholders unexpectedly changed the governance model of the bank and readopted the traditional one from 2009. The company declared that this choice was the consequence of the new rules issued by the Bank of Italy (4 March 2008) that assigned a control function to the supervisory board and a management function to the management board, so prohibiting members of the supervisory board of a bank from sitting on the boards of directors of its subsidiaries. In 2010, the shareholders of Mediobanca appointed Renato Pagliaro as chairman of the board, and on 28 October 2014, Maurizia Comneno as deputy chairman.

All these changes significantly affected the composition of the board. Tables 1.4 and 1.5 show the board of directors of Mediobanca in office in 2005, 2010 and 2014. In 2005, the board consisted of 20 members, five qualified as independent and only one female. The characteristics of the board were quite similar in 2010, as it consisted of 21 members, five qualified as independent and two women. In 2014, the board composition had changed radically, as half of the board members were qualified as independent and there were three female directors.

The number of directorships held by Mediobanca board members in other Italian listed companies decreased from 48 to 13 between 2005 and 2014. The main reason behind this trend was a new law in force since 2011 and aimed at reducing the interlocking directorates. The so-called Decreto Salva Italia bans a director from holding more than one board seat in companies competing in banking, insurance and financial services.

The board of directors in office in 2015, appointed by shareholders in a general meeting held on 28 October 2014, consisted of 18 members, with eight independent and five female directors. ${ }^{5}$ Table 1.6 shows the evolution of the corporate governance of Mediobanca over time and highlights that ownership concentration and interlocking directorates diminished, while independent and female directors increased. Probably also due to the changes in corporate governance, foreign institutional investors had increased their shareholding up to about 35 percent of equity at the end of September 2014.

Fourth, the strategy and the business model changed radically due 


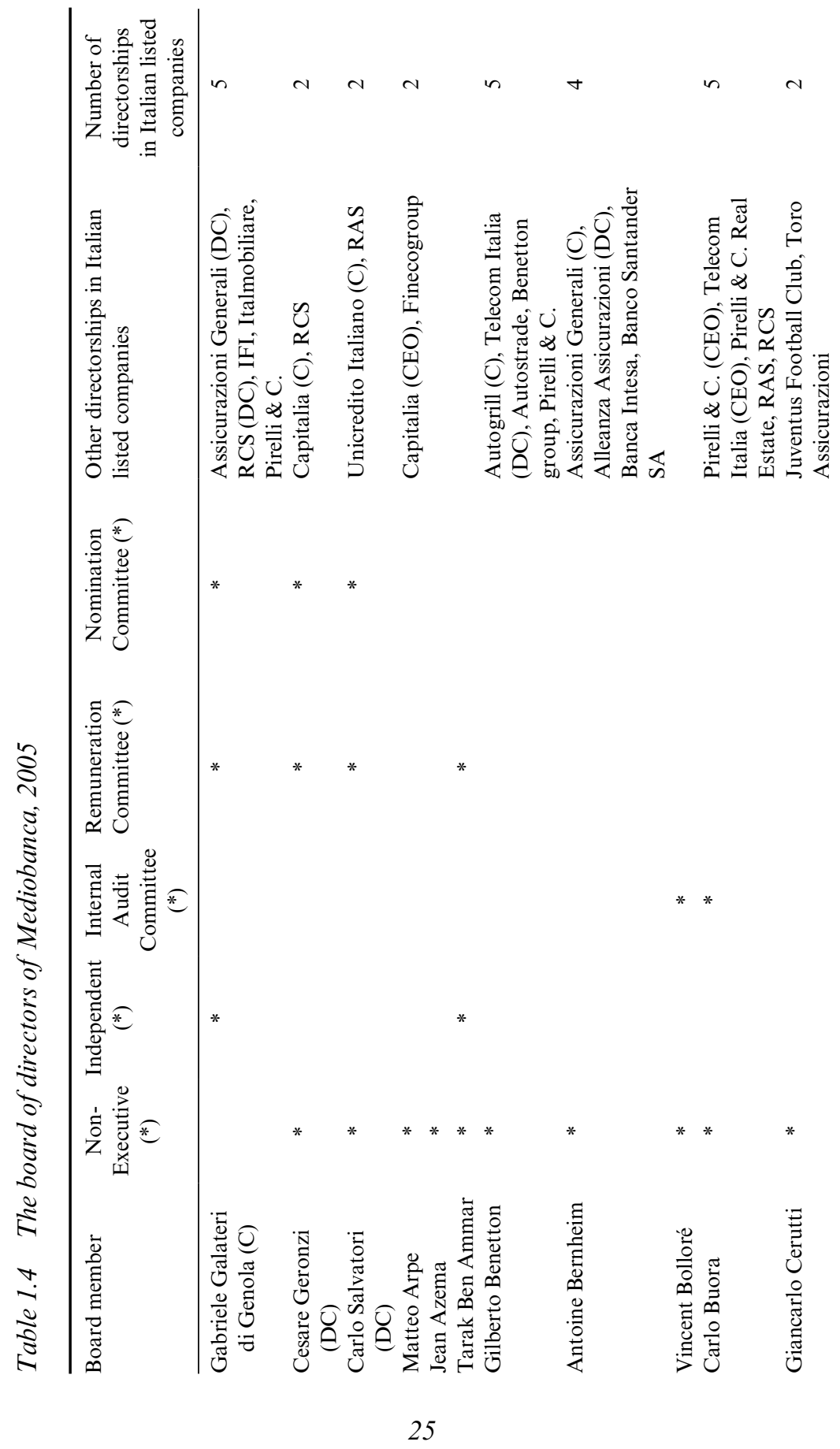




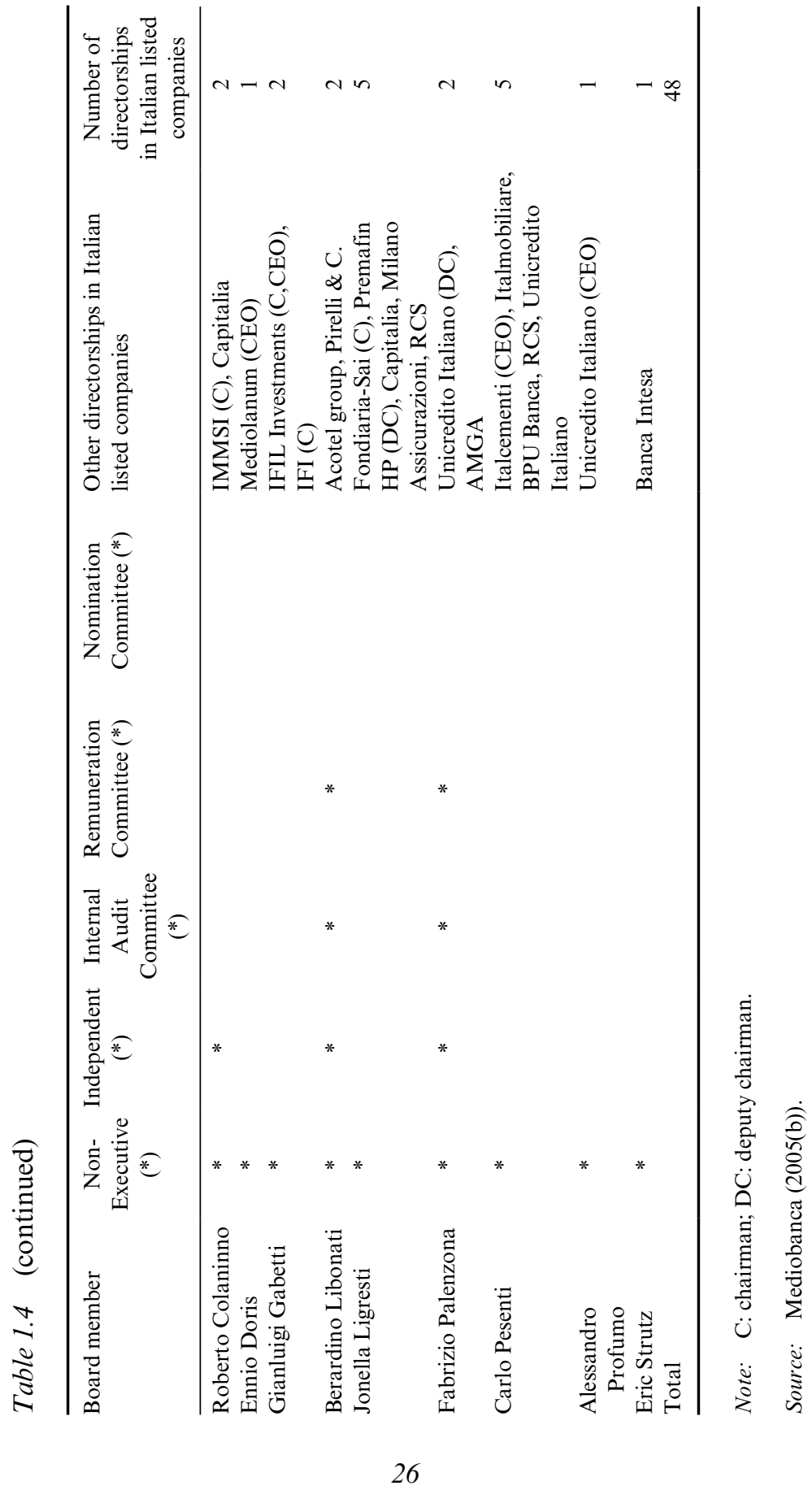




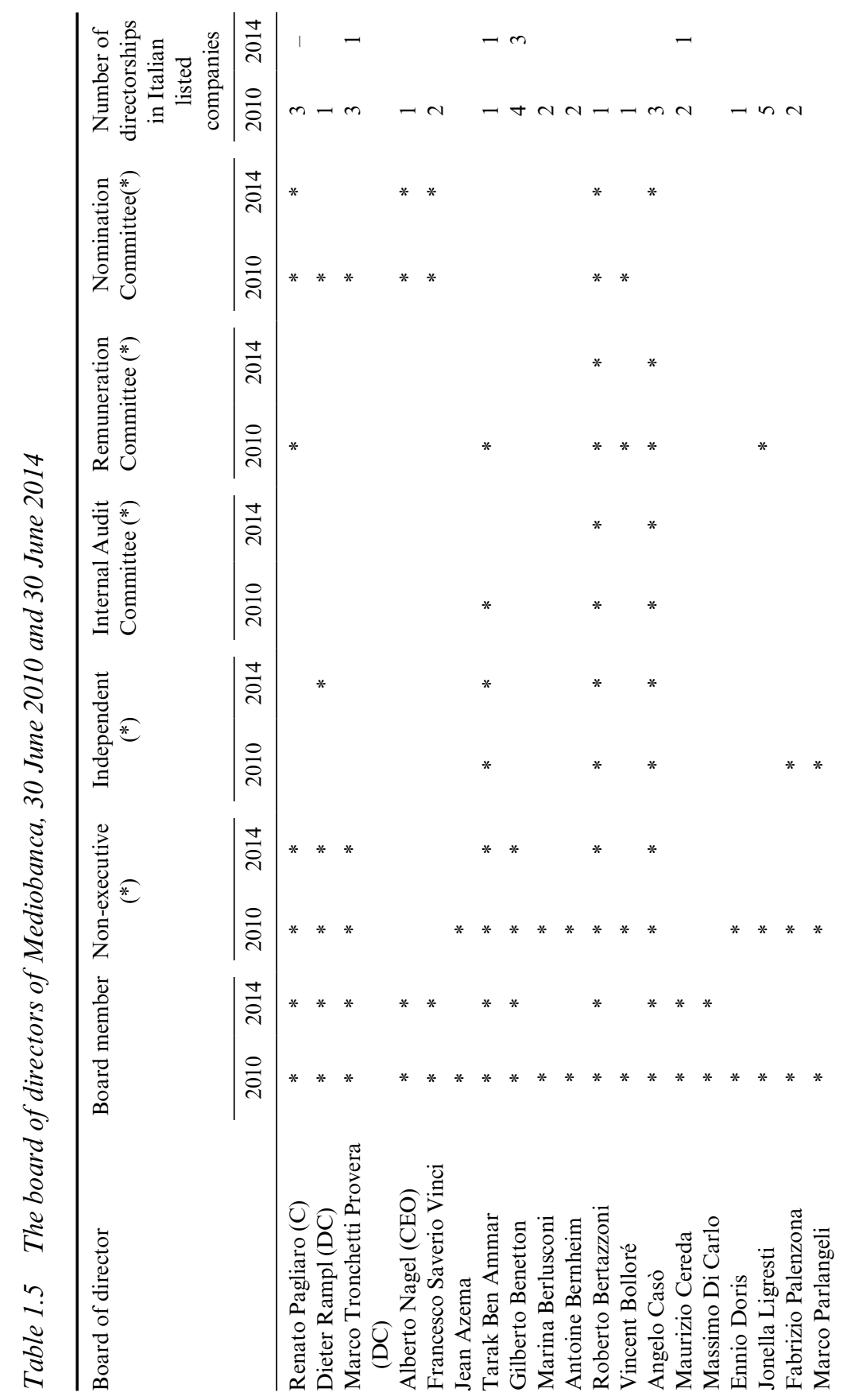




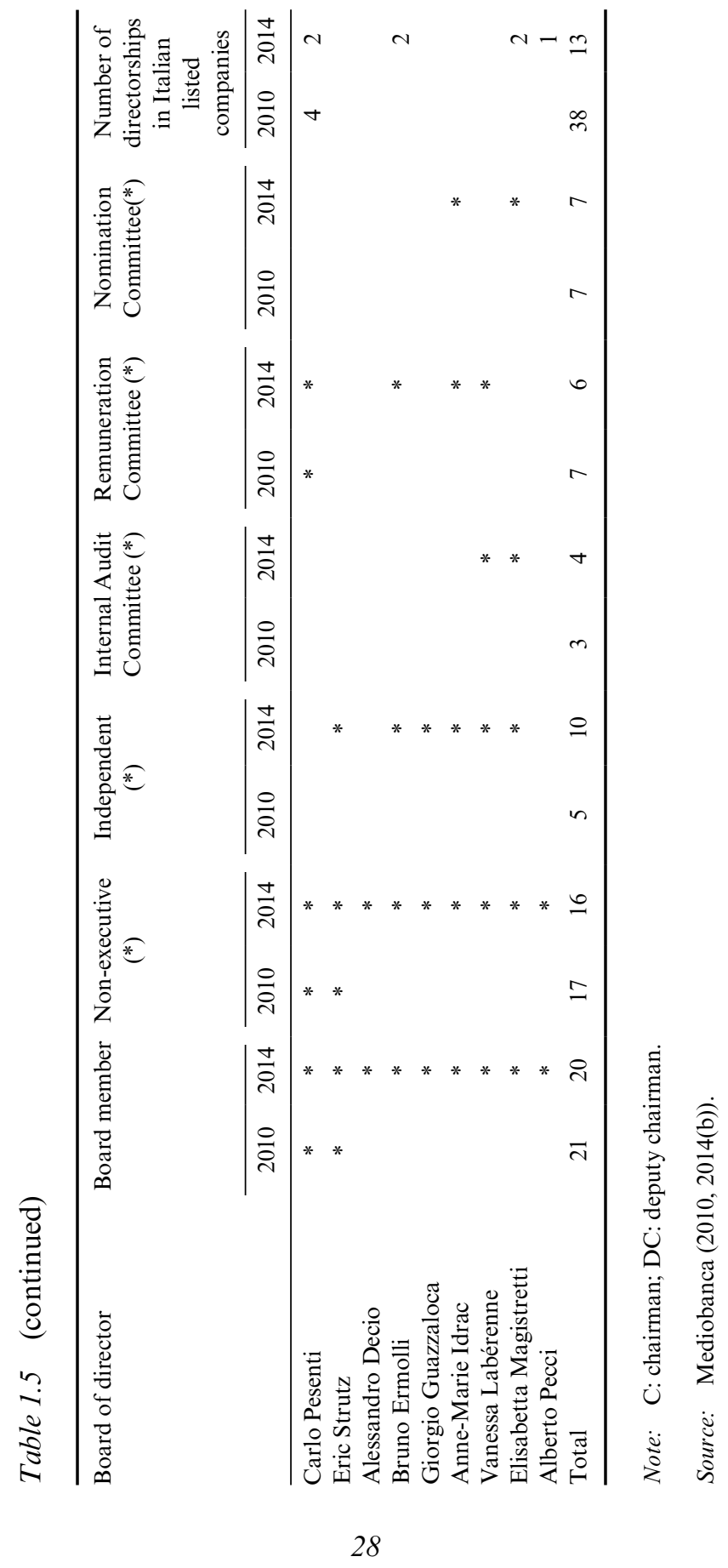


Table 1.6 The evolution of the corporate governance of Mediobanca, 2005-2015

\begin{tabular}{lcccc}
\hline & June 2005 & June 2010 & June 2014 & June 2015 \\
\hline $\begin{array}{l}\text { Shareholders' agreement } \\
\quad \% \text { of share capital) }\end{array}$ & 54.69 & 44.27 & 30.05 & 31.44 \\
$\begin{array}{l}\text { Board of directors } \\
\text { Number of directors }\end{array}$ & 20 & 21 & 20 & 18 \\
$\quad \begin{array}{l}\text { Number of independent } \\
\quad \text { directors }\end{array}$ & $5 / 20$ & $5 / 21$ & $10 / 20$ & $8 / 18$ \\
$\begin{array}{l}\text { Number of female directors } \\
\text { Number of other directorships } \\
\quad \text { in Italian listed companies }\end{array}$ & 1 & 2 & 3 & 5 \\
\hline
\end{tabular}

Source: Mediobanca (several years(b)).

to the evolution of the previous variables. At the beginning of the new millennium, Mediobanca owned a number of shareholdings in several Italian listed companies. The most important shareholdings included 15 percent of Compart, 13.29 of La Fondiaria Assicurazioni, 12.77 percent of Gemina, 9.5 percent of Italmobiliare, 9.26 percent of Assicurazioni Generali, 9.17 percent of Ratti, 7.49 percent of Safilo, 6.29 percent of Falck and 5 percent of Pirelli. Other relevant shareholdings, between 1 and 5 percent of the share capital, were held in large private groups, that is, Cofide (De Benedetti group), Fiat, GIM (Orlando family), SAI (Ligresti group), Marzotto, Snia, Stefanel, Olivetti and Pininfarina. Finally the bank held a large majority of savings shares (that is, shares with no voting rights) of three companies (Pininfarina, Snia and Stefanel), but in this case the main rationale could be speculative reasons.

Then, the bank drastically reduced the shareholdings aimed at stabilizing the control of large private Italian companies and expanded both the investment bank and the retail banking businesses. On the one hand, it sold its 15 percent shareholding of Compart (now Montedison) to Italenergia when the latter launched a takeover on the firm in 2001; with this move, the bank cancelled its historical link and support to the largest Italian chemical group. In addition, under Alberto Nagel as the CEO, the bank divested $€ 6$ billion of equity between 2004 and 2014. As a consequence, Mediobanca owned only a few shareholdings in other Italian listed companies at the end of June 2014. These shareholdings included 13.24 percent of Assicurazioni Generali, 9.50 percent of Italmobiliare, 6.2 percent of RCS and 4.61 percent of Pirelli. 
On the other hand, Mediobanca created - together with Mediolanum the joint venture DueMme (later renamed Banca Esperia) to develop a high-end firm in the private banking industry in 2000. It bought 44.35 percent of the Compagnie Monegasque de Banque to gain its control in 2003, and the residual 38.36 percent of share capital in 2004. It renamed Micos Banca - constituted in 1992 to operate in real estate finance - as Che Banca! and extended its range of operations to include a multi-channel (internet, call center and retail) bank. It bought - through the subsidiary Compass - 100 percent of Linea, operating in consumer credit. In addition to establishing new companies or taking the control of existing ones, Mediobanca opened new branches in Europe - Paris (2004), Frankfurt and Madrid (2007) and London (2008) - and created new subsidiaries, first in New York (2007) and later in Istanbul (2013) (R\&S, several years).

Despite all these changes, the transition from the old to the new business model was not immediately accomplished due to some inertia implicit in the bank. In some cases, Mediobanca continued to play an active role in stabilizing the control of large national groups such as Telecom Italia. In particular, the bank transformed its minority shareholding in Telecom Italia (equal to 1.54 percent) in an important shareholding (equal to 10.6 percent) of Telco in 2007, and later increased its shareholding to 11.6 percent when Sintonia (Benetton family) sold its stake in 2009. This operation mimicked the logic of the past by stabilizing and keeping under the control of Italian shareholders the country's largest telecom company. ${ }^{6}$

In addition, the overall network created by Mediobanca (the so-called Mediobanca galaxy) continued to play a prominent role in 2008 (Drago et al., 2011). While its importance decreased in terms of both market capitalization and the number of interlocks within the galaxy, it was still the major network among the Italian blue chips in 2008. The characteristics of the network (that is, the ownership structure of companies belonging to the galaxy) evolved in the decade between 1998 and 2008: (1) among the major shareholders of Mediobanca, there was only one bank (Unicredit), while the companies, including several wealthy entrepreneurial families (Berlusconi, Pesenti, Benetton, Ligresti and Zaleski), played an increasing role; (2) the influence in the national economy was reduced and mainly exercised through the major affiliated company (Assicurazioni Generali, one of the largest European insurance companies) which held significant shareholdings in several large companies, including an insurance company (Alleanza), a large bank (Intesa Sanpaolo) and a few industrial groups (for example, Telecom, Pirelli, Impregilo, Autogrill, Atlantia).

In sum, despite some structural inertia in its choices and operations, in the new millennium the ownership, governance and strategy of Mediobanca were drastically changed with respect to the past 
decades. Recent choices clearly testify to this transition. Instead of continuing to support the stability of Telecom Italia's shareholding structure, Mediobanca favored the dismantling of Telco to receive freely disposable shares of the largest telecom operator in Italy. Moreover, at the renewal of Mediobanca's syndicate agreement in January 2014, Groupama group, Unipol and even Assicurazioni Generali terminated their involvement in the syndicate.

\section{CONCLUSIONS}

The history of Mediobanca is intertwined with the history of the Italian banking industry and of the Italian capitalism model. It is a controversial history, as the commentators and the scholars did not develop a common opinion about the positive and negative consequences of Mediobanca in the period in which it was the 'kingmaker' of the national economy.

Mediobanca was created just after the end of the Second World War, in a period when the national banking law clearly separated commercial and investment banks. It was an investment bank that could lend financial resources in the long run, support financial operations of industrial and financial groups (for example, issues of bonds or capital increases), and buy their shares and bonds. It was a special investment bank as its founding shareholders were the three major Italian banks that supported its operations by both distributing shares and bonds of large industrial groups among the public, and financing its development by subscribing to its capital increases and buying its bonds.

In a period in which the banks and a large part of the national economy were under the control of the state, Mediobanca and its leader Enrico Cuccia aimed at operating with high autonomy from the shareholders in order to scrupulously select the companies to finance: that is, companies with a good credit rating and promising business prospects. Through his personal relationships and his intellectual acumen, Cuccia succeeded in stabilizing the control of Mediobanca by involving private companies and financial institutions as shareholders, and then by promoting a syndicate agreement whereby state-owned and private shareholders had the same weight. In such a way he created a 'centaur', a half-private and half-state-owned financial institution, where the top management team had full autonomy to pursue the objectives of the institution.

Mediobanca strongly influenced the characteristics of Italian capitalism. Cuccia's main objective was to protect the Italian private industrial and financial groups from state dirigisme and unexpected financial crises. Based on the premises that helping private companies was synonymous 
with supporting the national economy, Mediobanca supported the stability of the ownership structure of large industrial groups through consolidations and financial operations. In Cuccia's view, the stability of control was a necessary condition to guarantee the long-term strategic development of industrial firms.

However, stability of control in the same hands for a long period can produce both positive and negative effects on firm performance. On the positive side, stability of control by large groups allows wealthy entrepreneurial families and top management teams to develop strategic plans and investments aimed at sustaining the long-term growth and competitiveness of the companies. In addition, major shareholders have the incentive and the power to prevent top managers from deviating from value creation by pursuing either personal objectives or short-term profitability. Finally, Mediobanca played the key role of 'white squire' by providing the strategic advice and financial resources to contribute to the survival of large private groups facing a tough financial and industrial crisis, such as Fiat or Montedison in the 1970s and 1980s (Zattoni, 1999, 2000).

On the other hand, ownership stability can be seen as an obstacle to the creation of an efficient market for corporate control that allocates the majority shareholding of a firm to the most suitable investors. In addition, the large and complex pyramidal groups, created to stabilize control in the hands of the wealthy entrepreneurial families, created a structural conflict of interests between majority shareholders of the holding company and minority shareholders of the subsidiaries. Such groups can incentivize majority shareholders to maximize their own wealth at the expense of minority shareholders, for example by moving assets within the group at favorable prices for the top holding companies where they have higher cash flow rights (so-called 'tunnelling'). Finally, stability of control has also been achieved through the creation of fragile financial structures that in the long run have led to a reduction in the growth ambition and the postponement of key investments aimed at strengthening the competitive position of the group in the international arena (Zattoni, 1999).

Beyond the consequences for large private groups and their stakeholders, commentators have also analyzed the impact of the efficiency of the market for corporate control. From this perspective, they observe that the financial and strategic support provided to the large private groups belonging to the 'galaxy of the north' may have penalized the market for corporate control and the long-term growth of the national economy. In other words, they underline that Mediobanca has protected a few large entrepreneurial families and their companies, but at the expense of inhibiting change of control at the top of their groups, including when their strategic plans were not particularly effective. The lack of an active market 
for corporate control could also have undermined the emergence of new actors with more innovative and ambitious entrepreneurial projects (Piluso, 2005).

In sum, the history of such a singular and powerful bank and of its longtime leader Enrico Cuccia - the best European banker of his time according to André Meyer of Lazard - provides several insights for corporate governance scholars and practitioners. The story of Mediobanca is not yet finished, but with the demise of its founder and leader of 50 years, it is diverging significantly from the past.

\section{NOTES}

1. The multiple loans practice, diffused in Italy since the 1970 s, consists of creating a bank credit with several commercial banks. This practice reduces the banks' risk as firms can obtain financial resources from several financial institutions. At the same time it both reduces the information flow from the firm to the banks, and favors an increase in the leverage of the firm.

2. In the Italian traditional corporate governance model, shareholders appoint both a board of directors (consiglio di amministrazione) and a board of statutory auditors (collegio sindacale). The main task of the board of statutory auditors is to monitor the organization, information and lawfulness of the board of directors (Melis, 2004).

3. At the end of October 2014, Mediobanca revised its Articles of Association. The main changes refer to the new terms for appointments to the board. In particular, at least one-third of the directors shall qualify as independent and five will be chosen among employees with at least three years' experience within the Mediobanca group at senior management level. Directors are appointed on the basis of lists. One list of candidates shall reflect the preferences of the members of the shareholders' agreement pro rata. In addition, the list shall include two deputy chairmen: one proposed by Unicredit and the second proposed by Bolloré group and supported by the other shareholders. Approval of this list shall require a majority of two-thirds of the shares. Regarding the list of candidates for appointment to the statutory board, one effective member is proposed by Unicredit and two by the other members of the shareholders' agreement (that is, only one is elected if a minority list is presented). The chairman of the statutory board is appointed from a list submitted by the minorities or, if no minority list is submitted, is the member proposed by Unicredit (Mediobanca, 2014(a)).

4. The general reform of corporate law enacted by the Italian government in 2003 introduced, in addition to the traditional model characterized by the presence of a board of directors and a board of statutory auditors, two supplementary models of corporate governance: (a) a 'dualistic' model, with a two-tier board of directors consisting of both a supervisory board and a management board; and (b) a 'monistic' model, with a one-tier board of directors characterized by the presence of (at least) one-third independent directors, and of an audit or control committee composed only of independent directors (Zattoni, 2009).

5. The increase of female directors in Mediobanca is mostly due to the Law 120 issued in 2011. According to this law, in the first board election after August 2012 all boards should be composed of at least 20 percent female directors and in the second and third elections at least one-third female directors. The law is effective until 2022.

6. Telco was the majority shareholder of Telecom Italia between 2007 and 2015. Generali, Mediobanca, Intesa Sanpaolo and Sintonia held 58 percent of Telco, while Telefonica held the remaining 42 percent. In June 2015 the board of directors of Telco decided to allocate all shares of Telecom Italia (equal to 22.3 percent) to its shareholders pro quota. 


\section{Handbook on corporate governance in financial institutions}

\section{REFERENCES}

Brioschi, F., Buzzacchi, L. and Colombo, M.G. 1990. Gruppi di imprese e mercato finanziario. Roma: La Nuova Italia Scientifica.

Colajanni, N. 1991. Il capitalismo senza capitale. Milano: Sperling \& Kupfer.

Drago, C., Manestra, S. and Santella, P. 2011. 'Interlocking directorships and crossshareholdings among Italian blue chips'. European Business Organization Law Review, 12: $619-652$.

Gerschenkron, A. 1962. Economic Backwardness in Historical Perspective. Cambridge: Belknap Press.

La Malfa, G. 2014. Cuccia e il segreto di Mediobanca. Milano: Feltrinelli editore.

McCann, D. 2000. 'The Anglo-American model, privatization and the transformation of private capitalism in Italy'. Modern Italy, 5(1): 47-61.

Mediobanca. Several years(a). 'Annual Report'.

Mediobanca. Several years(b). 'Annual Statement on Corporate Governance and Ownership Structure'.

Melis, A. 2004. 'On the role of the board of statutory auditors in Italian listed companies'. Corporate Governance: An International Review, 12(1): 74-84.

Piluso, G. 2005. Mediobanca. Milano: Egea.

Piluso, G. 2010. 'From the universal bank to the universal bank: a reappraisal'. Journal of Modern Italian Studies, 15(1): 84-103.

R\&S. Several years. 'Mediobanca'.

Segreto, L. 1997. 'Models of control in Italian capitalism from the mixed bank to Mediobanca 1894-1993'. Business and Economic History, 26(2): 649-661.

Zamagni, V. 2009. 'Governing the Italian economy: a comparative perspective'. Journal of Modern Italian Studies, 14(1): 46-51.

Zattoni, A. 1999. 'The structure of corporate groups: the Italian case'. Corporate Governance: An International Review, 7(1): 38-48.

Zattoni, A. 2000. Economia e governo dei gruppi aziendali. Milano: Egea.

Zattoni, A. 2006. Assetti proprietari e corporate governance. Milano: Egea.

Zattoni, A. 2009. 'Corporate governance in Italy: the structural conflict of interests between majority and minority shareholders'. In Lopez Iturriaga, F.J. (ed.), Codes of Good Governance Around the World. New York: Nova Publishers.

Zattoni, A. and Cuomo, F. 2015. 'Institutional change and ownership patterns in Italy'. In Goranova, M. and Verstegen Ryan, L. (eds), Shareholder Empowerment. New York: Palgrave Macmillan. 